\title{
Non-compassionate care: a view from an Islamic charity organization
}

\author{
Amira Mittermaier ${ }^{1}$ (D)
}

Accepted: 13 December 2020/ Published online: 15 February 2021

(C) The Author(s), under exclusive licence to Springer Nature B.V. part of Springer Nature 2021

\begin{abstract}
Drawing on fieldwork at a large charity organization in Cairo, this article describes a bureaucratized Islamic ethics of care. Founded in 1975, the Mustafa Mahmoud Association today offers free and discounted medical services, funds micro-projects, and provides financial support to about 10,000 families each year. The bulk of that financial support comes from donors' private donations in the form of obligatory and voluntary alms (zakāt and sadaqa). By taking a close look at three offices - the donation, intake, and disbursement office-I untangle the regime of care that shapes the daily transactions at this Islamic charity organization. In particular I highlight a significant gap between "caring for" and "caring about." Donors view caring for those in need as a duty and frequently frame their donations in calculative terms, as a way of "trading with God." Less central is a language of empathy or compassion. While this seemingly careless care-less? Careless means not careful, sloppy. form of caremight seem cold and heartless, I suggest that it offers a powerful alternative to the liberal illusion of "compassion."
\end{abstract}

Keywords Islamic charity · Egypt · Alms · Bureaucracy $\cdot$ Compassion · Humanitarianism · Mustafa Mahmoud Association

\section{Care of the self, care for others}

Since the early 2000s, much anthropological literature on Islam has foregrounded practices of "self-cultivation" or what Foucault (1988) has termed "care of the self" (e.g., Hirschkind 2006, Jouili 2015, Mahmood 2005). This concept has offered an important corrective to an earlier overemphasis of belief, symbols, and meanings (Asad 1986). It has shifted the analytical and ethnographic focus to embodied practices and to

Amira Mittermaier

amira.mittermaier@utoronto.ca

1 Department for the Study of Religion, University of Toronto, 170 St. George Street, 3rd floor, Toronto, ON M5R 2M8, Canada 
the ways in which practitioners inhabit, and shape themselves in line with, their religious traditions. "It is a modern idea," Talal Asad (1993:36) notes, "that a practitioner cannot know how to live religiously without being able to articulate that knowledge."1 While opening up new fields of inquiry, the concept of self-cultivation has been criticized for prioritizing exceptional pious pursuits over "the everyday" (Schielke 2010) and for backgrounding the ways in which the Divine acts upon Muslim selves (Mittermaier 2012). This article does not aim to add yet another corrective. While shifting the focus from the paradigm of self-cultivation to modes of caring for others, I seek to show that these two modes of care are in fact intimately intertwined. Reading them alongside each other opens up critical insights into an Islamic ethics of care that decenters an ethos of compassion which, in anthropology and public imaginaries alike, tends to be closely associated with charity. Through a close look at an Islamic site of care, I seek to decouple charity from compassion.

Derived from the Latin com (together with) and patior (to suffer), compassion is defined in the Oxford English Dictionary as suffering together with another, fellowfeeling, and sympathy. Often the term implies not only being moved by the suffering of another but also the desire to relieve it. As such, compassion - as an idea and an idealis often taken to be the central driving force behind charity. As Omri Elisha (2011) notes, compassion is frequently understood as unconditional benevolence, which, in the context of the North American mega-churches he studies, inevitably yet paradoxically comes to be paired with accountability. Writing about Americans in Italy but here making a more general point, Catherine Trundle (2014:137) remarks that "charitable actors commonly describe compassion as a force that buttresses their motivations to offer support and alleviate suffering." The link (and slippage) between charity and compassion appears not only in scholarly accounts of philanthropic undertakings but also in broader public discourses, particularly when Christianity is imagined as the religion that introduced and elevated compassion. A Texas-based evangelical website praises Christianity for its unique embrace of compassion, describing it as a religion which "exploded onto a brutal, heartless Greco-Roman culture." It continues: "Believers in this radical new religion set a new standard for caring for the ill, downtrodden, and abused, even at risk of death... No other religion or philosophy values and practices wholesale taking care of the young, sick, orphaned, oppressed, and widowed, hands-on and sacrificially." Even though compassion is also a central element of other religious traditions, including Islam, ${ }^{3}$ here Christianity is celebrated as a religion that is quintessentially about compassion.

Rhetorically, charity and compassion often go hand in hand, and when the Christian model is secularized and transformed into "humanitarianism," compassion is easily

\footnotetext{
${ }^{1}$ The turn to self-cultivation and embodied practice undoes the dichotomy of conscious/unconscious. As Saba Mahmood (2005) argues in her landmark study on women's mosque study groups in Cairo, embodied practice and explicit pedagogy can go hand in hand.

${ }^{2}$ https://probe.org/charity-and-compassion-christianity-is-good-for-culture/; emphasis in original. Nietzsche, too, famously called Christianity the "religion of pity."

${ }^{3}$ Compassion figures in many ways in the Islamic tradition. As Muslims recall during every single prayer, God is al-rahmān al-rahim, the All-Compassionate, the All-Merciful. Many of my interlocutors in Egypt (especially Sufis) say that, in order to draw close to God, one needs to continuously try to emulate and embody God's attributes. Many Muslims care about and feel with those in need. At the same time, many of my pious interlocutors are suspicious of an overemphasis on "compassion" and even the concept of "doing good" ('amal al-khayr), which is used widely in Egypt as a catch-all phrase of "charity."
} 
universalized along with the underlying concept of "the human." In Humanitarian Reason, Didier Fassin illustrates the rise of humanitarian reason (and the co-current eclipsing of a logic of rights) through a range of examples, from French social welfare offices to Doctors Without Borders. His account of the rise of humanitarian reason is compelling, critical, and thorough and has been central to my thinking about different forms of care in Egypt. Fassin's own account is squarely centered on Christianity and its secular remnants. The two times he evokes non-Christian religious traditions and logics of giving, he subsumes them within the Christian-turned-universal paradigm. The first time occurs in the Introduction: "the paradigm of a politics of compassion... feeds Western morality well beyond the domain of Christian doctrine, which obviously has no monopoly on concern for the misfortune of others, whether we consider the central role of compassion in Confucianism and Buddhism or its translation as charity in Islamic and Jewish traditions" (1; emphasis added). The second time occurs in the Conclusion when Fassin highlights humanitarianism's entanglement with Western society because "the ethos from which [humanitarian reason] proceeds has its source in the Christian world - in terms of both the sacralization of life and the valorization of suffering." But then he adds, "although, of course, there are other traditions of compassion and charity, from Islam to Confucianism to Buddhism" (248). These alternative genealogies, trajectories, or even counter-narratives remain at the margins of Fassin's text — an afterthought of sorts. Taking a closer look at Islamic charity, I want to trouble the quick equation between different religious (and secular) regimes of care - and particularly the idea that compassion is translated into charity in Islam. I seek to offer insight into a regime of care that does not ride on compassion.

Concretely, I draw on fieldwork in Cairo between 2011 and 2013 and follow the flow of alms through a large charity organization: the Mustafa Mahmoud Association (henceforth also Mustafa Mahmoud). ${ }^{4}$ I look at three different offices: the donation office, the intake office, and the disbursement office. In each office, I listen to what the various participants in this charitable economy say about an Islamic ethics of care, and I pay attention to how they enact it on a day-to-day basis. Together, the three offices provide insight into what I call "non-compassionate care." At this Islamic charity organization, a logic of rights is not eclipsed by charitable giving. The two co-exist and are intimately intertwined. Rather than universalize compassion as intrinsic to all religious traditions, my ethnographic sketch of the three offices invites us to consider how a different religious regime of care might disrupt the centrality of compassion and of affect more broadly.

To prevent misunderstandings, let me emphasize that my argument is not that Islam is an uncompassionate religion. Such a claim would be problematic and feed into a longstanding stereotype of a violent, ruthless Islam. Sufi writings (and writings about Sufism) emphasize the role of love, and in the Quran, the sunna, and Islamic ethics more broadly, one finds a pervasive emphasis on divine and human mercy (rahma). To be clear then, I am not making an argument about Islam at large. Rather, I trace and

\footnotetext{
${ }^{4}$ I started visiting the Mustafa Mahmoud Association in 2003 during my earlier research on dreams and spent much time there in 2011, during my fieldwork on Islamic charity. I returned during follow-up visits in 2012 and 2013. Within my larger project, the Mustafa Mahmoud Association became an example of a bureaucratized site of care. NGOs are key players in Egypt's charitable landscape. In addition to fieldwork at NGOs, my research included practices of giving directly to the poor, food distribution (it 'a $\bar{m}$ ) (Mittermaier 2019, Naguib 2015), and Islamic voluntarism (Deeb 2006, Hafez 2011, Mittermaier 2014, Sparre 2013, 2018).
} 
unpack a particular ethics of care that is performed at one Islamic charity organization in Cairo in the years following Hosni Mubarak's ouster and in an era, more broadly, when a logic of hasanat (divine rewards for good deeds) has been appropriated by a capitalist ethics (Mittermaier 2013, Schielke 2015). Much of the uncompassionate nature of the care administered by the Mustafa Mahmoud Association can be attributed to the bureaucratization and formalization of care - a process that requires measuring and comparing need and documenting and assessing claims. While my previous work focuses more on direct and informal modes of giving (Mittermaier 2014, 2019), here I zoom in on a bureaucratized site that disrupts even more drastically the presumption of compassion. At Mustafa Mahmoud, the cruelty of bureaucracy merges with (and is inflected by) an Islamic care-economy.

Importantly, I do not read the seeming lack of compassion as a shortcoming but rather see it as a provocative challenge to the liberal illusion of compassion. As such, my ethnographic intervention is in dialog with other critiques of compassion. Lauren Berlant asks, "What if it turns out that compassion and coldness are not opposite at all but are two sides of a bargain that the subjects of modernity have struck with structural inequality?" (2004:10). She argues that compassion reinscribes privilege: the sufferer is over there. Compassion can also be self-congratulatory. Reflecting on the many donations given at times of natural disasters, Didier Fassin notes: "We lamen[t] their dead but celebrat[e] our generosity" (2012: ix). Or as he puts it elsewhere: "We love to feel pity" (ibid. 251). Compassion, furthermore, is selective. While some lives (and deaths) move us, others do not (Butler 2006). And even for the most caring and empathetic people, there is always the danger of "compassion fatigue." Other critics argue that the celebration of the ethos of compassion distracts from, and undermines, a framework of rights and justice. It is depoliticizing (Fassin 2012, Ticktin 2011). By disentangling an ethics of care from compassion, my tour through the Mustafa Mahmoud mosque-complex seeks to contribute to these efforts to critically think about (and beyond) compassion.

\section{The Mustafa Mahmoud Association}

At a main thoroughfare that runs through Cairo's upper-class neighborhood of Mohandeseen sits the Mustafa Mahmoud mosque-complex, home to the organization by the same name. It offers free and discounted medical services, funds micro-projects, and each year provides financial support to about 10,000 families in need. ${ }^{5}$ The association was founded by Mustafa Mahmoud (1921-2009), a formerly Marxist Muslim intellectual who became widely known through his popular television program Science and Faith. The money for the mosque-complex originally came from his

\footnotetext{
${ }^{5}$ Medical care is central to the organization. Medical caravans were gradually combined with self-help programs, aiming to mobilize the poor to help themselves. Today, in line with a broader turn to development and sustainability across Egypt's NGOs (see Atia 2013), Mustafa Mahmoud offers loans for small entrepreneurial projects and channels alms donations into projects with long-term benefits, such as giving cows to poor families in Upper Egypt, planting palm trees, and digging wells. These projects are mostly funded through sadaqa gāriyya, donations given with an eye to long-term benefits. Zakat donations for the most part still get channeled into monthly monetary aid for select families, in line with the principle that one cannot tie expectations to zakat donations.
} 
private savings, supplemented by support given by Qatari and Kuwaiti donors. Today the bulk of the organization's funds comes from Egyptians' private donations: obligatory alms (zakāt) and additional offerings (sadaqa). ${ }^{6}$

Founded in 1975, the Mustafa Mahmoud Association remains one of the more popular places in Cairo to which wealthy Egyptians entrust their alms. It has been described as the "most significant case of public Islam in post-Nasserist Egypt" (Salvatore 2000:13). ${ }^{7}$ Despite the growing competition with more recently established charity organizations, such as Dar al-Orman, Resala, and the Egyptian Food Bank (founded in 1993, 1999, and 2006 respectively), many middle- and upper-class Egyptians continue giving to Mustafa Mahmoud. Some told me they prefer this somewhat old-fashioned organization to the newer ones because it does not waste any of its funds on media advertisements. The organization's reputation rides on its history, its renowned medical centers, and the respect many Egyptians hold for its founder.

In many ways, the Mustafa Mahmoud Association is a typical bureaucratic institution. Its administrative structure is hierarchical. Its offices are cluttered with folders, registration cards, and spending reports. It is regularly audited by state officials. Its employees spend much of their time joking, gossiping, drinking tea, feeling bored, and filing documents. ${ }^{8}$ In response to my questions about the Islamic underpinnings of the daily transactions at the organization, the Human Resources director told me during one of my earlier visits that for the employees, "this is simply a job, like any other job." At first sight, Mustafa Mahmoud is no different than any other NGO or welfare office around the world.

But the money that flows through this mosque-complex - the bills that are counted, stacked, and handed out by its employees every day-is not just any money. It is money that was given to God (li-llāh) with the intention of it being alms (zakāt or sadaqa). ${ }^{9}$ Once transfigured into alms, the money becomes what the Quran conceptualizes as the "right of the poor" (haqq al-faqīr). Mustafa Mahmoud is therefore not simply a bureaucratic machinery. It is also a site where an Islamic ethics of care is lived, cultivated, and negotiated every day. The founder, Mustafa Mahmoud, grounded his entire philanthropic enterprise in the idea that "mosques are not just for prayer." 10 As

\footnotetext{
${ }^{6}$ In Ramadan, additional donations make up for missed days of fasting (for oneself or for elderly or sick relatives). The required payment is called kafära, and each missed day of fasting needs to be made up by paying for food for a fasting person for the day, including the meal to break fast in the evening (iftär) and an early morning meal before sunrise (suhūr). In 2011, it was calculated that 15 EGP were needed for the former and 5 EGP for the latter; feeding a person throughout the month thus amounted to paying 600 EGP. Some also give money for the Ramadan table (mä'idat al-rahmān)that is organized by the mosque. Additional funds come from fees paid by patients (those who can afford to pay) at the organization's medical clinics.

${ }^{7}$ On the Mustafa Mahmoud Association, see also Atia (2013), Clark (2004), Salvatore (2001), and Sullivan (1994).

${ }^{8}$ At the time of my fieldwork, 234 employees worked at the mosque-complex (the number increases to 1200 if one includes the medical branches of the Association with hospitals in other locations in Cairo). The salaries are on the low side, for most employees around $350 \mathrm{EGP} / \mathrm{month}$ (a few more longstanding employees made closer to $1200 \mathrm{EGP} / \mathrm{month})$.

${ }^{9}$ Though used interchangeably in the Quran, zakāt is today taken to refer to obligatory alms donations (one of the five pillars of Islam). Sadaqa is taken to refer to additional voluntary donations.

${ }^{10}$ Mustafa Mahmoud was born in the Nile Delta in 1921. He was a medical doctor and practiced medicine from 1952 to 1966. Subsequently, he worked as a journalist and author and became a public intellectual. He is best known for his TV series al- 'ilm wa al-imān(Science and Belief) which presented scientific insights as signs of God's workings in the world. Mahmoud advocated an "Islamically inspired modernity" that emphasizes creativity and adaptation as a method (Salvatore 2000:12). Armando Salvatore describes him as "a normative entrepreneur able to invest the moral view of individual responsibility, social obligations, and imperatives of progress" (ibid.).
} 
his daughter told me, he built the mosque and founded the association because of a dream he had seen - a divine sign that compelled him to redirect his savings toward a charitable purpose. (Previously, she told me, he had wanted to spend the money on a yacht.) $)^{11}$

The Mustafa Mahmoud Association is thoroughly bureaucratic, but it is also a site of piety, one in which self-care merges with the care for others. For some of the employees, working in the mosque-complex is precisely not "like any other job," but it is a job that allows them to partake in a divine economy. An employee in his fifties, who spends his days punching numbers into a computer in a small office at the mosque, confided in me his frustrations: the meager salary, his chronic back pain, and the pervasive boredom that comes with his work routine. He paused and added: "But I like working here. It's a way of drawing closer to God" (a'arrib min rabbinnā). Employees, donors, petitioners, and recipients repeatedly framed the daily transactions at Mustafa Mahmoud, the giving and receiving, in relation to the Islamic tradition.

As in other welfare contexts, charity at Mustafa Mahmoud can be cruel. To recall Judith Butler and other critics, regimes of care privilege the suffering of some over that of others. Charity, moreover, in many places comes with strings attached: the obligation to adequately perform one's suffering, to be grateful, and to reciprocate in some form. For this reason, Mary Douglas (1990) speaks of the "wounding" character of charity. But unlike in other charitable contexts, giving at Mustafa Mahmoud is not tied to an ethos of compassion but rather is organized around a concept of duty. As a consequence, as we will see, care for others here cannot neatly be separated from care of the self. ${ }^{12}$ Giving at Mustafa Mahmoud is seemingly directed at those in need. At the same time, it is unapologetically selfish and non-compassionate. For recipients, this non-compassionate form of care means that they do not get much social capital out of their ostensible suffering; their stories of hardship often fall on deaf ears. But it also means that when they receive alms, they are receiving divine provisions - and not "crumbs from the rich man's table" for which they ought to be grateful like "petted animals," as Oscar Wilde (1895) put it in his late nineteenth century critique of charity. The poor here might not be met with compassion. But neither do they have to enact the scripts associated with humanitarian reason.

\section{The donation office}

Despite having received permission from the administration to move around as I pleased, my fieldwork at Mustafa Mahmoud was often stationary. It involved hours of sitting and watching. One of my regular spots was in the small donation office (maktab al-tabarru'ât) right beside the entrance to the mosque. Two middle-aged women work in this office. At first ambivalent about my presence, they eventually began including me in their rounds of tea-drinking and offered me a spot in a corner from which I could observe the flow of people coming in every day to donate. Some

\footnotetext{
${ }^{11}$ Author's interview with Amal Mahmoud, Mustafa Mahmoud's daughter, 11 November 2011.

12 This is not to deny that giving out of compassion can also be a form of care of the self, such as when one takes pleasure in one's self-image of "compassionate giver." What I want to highlight, however, is the ideal of selflessness and other-oriented care that seem to often be associated with "compassion."
} 
donors were on their way to the mosque, about to join one of the five daily prayers, and spontaneously decided to stop by the office and make a contribution. The great majority of donors, however, had come to the mosque-complex, often from afar, with the sole intention of dropping off their annual zakat payment. Sticking around for some chitchat, a number of them explained to me why they were donating. A few tied almsgiving to the goal of solidarity (takâful) or, in the aftermath of the 2011 uprising, to "social justice" ( 'adāla igtimā 'iyya), often recycling the popular claim that if everyone in the world gave zakāt, there would be no poverty. The great majority of donors emphasized a different motivation: they give because they want to purify their remaining wealth. Literally, zakāt means "purity," which is generally understood to imply that by donating the obligatory $2.5 \%$ of one's assets (and 10\% of one's crop, and one out of forty animals), one cleanses and protects one's remaining wealth.

One might be tempted to read this Islamic logic of giving via Marcel Mauss's classical essay on the gift which addresses the convergence of self-interest and altruism. First published in 1925, the essay makes for an unsettling read if one presumes that gifts are (or should be) selfless gestures of generosity. Mauss (1967) argues that gifts always carry within them the expectation of a countergift. All gifts are self-interested. Through the constant exchange of gifts and countergifts, social relations are established and maintained. Reflecting on Mauss's intervention, Jonathan Parry (1986) suggests that the very idea of a selfless gift remains so persistent precisely because it functions as an almost-mythical counterpoint to market ideologies. Yet, as we see in Mustafa Mahmoud's donation office, the myth of the "free gift" does not have the same hold around the globe. The pretense of selflessness becomes unstable within this nonChristian, non-secular economy of giving. At Mustafa Mahmoud, there is no shame in admitting that one's central motivation for giving revolves around one's own wellbeing - be it in this world or in one's afterlife.

After she had handed a stack of cash-10,000 EGP (more than USD 1650) — to one of the employees, a wealthy-looking woman waited in the donation office while the money was run through a counting machine. In the meantime, she explained to me why she painstakingly meets all her alms obligations: to protect her property and to make sure "[her] remaining money does not get stolen and that [her] bank does not go bankrupt." Another donor, a middle-aged man, put it this way:

When you give, you receive baraka (divine blessings). Your money is purified. You might be able to afford only one piece of meat for your family but it will be enough for them. In another house, they eat five large pieces of meat and afterwards are still hungry. If there is baraka in your house, your wife won't ask every day for new clothes, and the fridge won't break. If you give, you have baraka.

Here the act of giving improves one's lot in this world-not necessarily by increasing one's material belongings (more money and the ability to buy more meat), but by increasing one's spiritual blessings (feeling full after just taking one bite). Other donors related their charitable giving to the goal of building for themselves "a house in paradise" (see Atia 2013, Schielke 2015). In both cases, giving is ostensibly a form of care of the self. It revolves less around "social relations," as in Mauss's account, but rather around a hoped-for countergift from God. It is vertically motivated, not horizontally. Of course, one cannot easily delimit the social from the divine, and God-human 
relations often manifest in, or shape, human-human relations. But, as I argue in my larger work on Islamic charity (Mittermaier 2019), an orientation toward God also decenters the human as the key organizing principle of ethics.

Squeezed into my corner in the office, I watched people make donations day after day. They would drop off anything from 20 EGP to 10,000, 20,000, or even 50,000 EGP (i.e., between about 3 and over 8000 USD) - all in cash. In the early 2000s, the organization claimed to be receiving one million pounds or more in donations every month (i.e., around 160,000 USD) (Atia 2008:198). One day in Ramadan 2011, I scribbled down the following numbers when the employees were counting the donations from that day alone: 126,000 EGP (21,000 USD) in cash plus one cheque for 30,000 EGP (5000 USD). These are considerable amounts in a context where many people struggle to get by and not only the well-off donate. Those not required to pay zakat (because they lack the extra wealth) still often give voluntary donations in the form of sadaqa. Notably, donations had decreased at Mustafa Mahmoud compared to previous years, a decline that the employees attributed to the growing competition between charity organizations, the worsening economic conditions in post-uprising Egypt, and the fact that, for many donors, trust in the organization had been contingent on the presence and oversight of its founder and had decreased after his death.

Yet even in these dire times, I was continuously struck by the constant flow of money into the mosque-complex and by the donors' firm commitment to giving. Whereas in North America many people exert remarkable efforts to find ways to lower their tax bills - using what websites advertise as "tax minimization strategies"- here people came in without being pressured by the state and without anyone knocking on their door to ask for donations, appealing to their conscience and compassion. No one was keeping track on how much they owed - other than they and presumably God. Almsgiving, first and foremost, is a deal between the believer and God. In line with this orientation, I never saw the employees in the donation office express surprise at, or appreciation for, the amounts given, even exceptionally large ones. They would count the bills by hand or run them through their counting machine, stick them into their desk drawer, and hand the donor the obligatory receipt. Sometimes a brief conversation would ensue; most times the transaction was formal, resembling that in a bank. Often donors asked the employees to simply write fă il khayr (literally, "doer of good") on the receipt instead of their name. To me this was yet another reminder that, for the donor, the only relevant record of the transaction was a divine record.

Giving at Mustafa Mahmoud is ostensibly selfish and not about feeling with, or caring about, others. Compassion for the recipients was rarely evoked in the donation office. In fact, donors often explained to me that they prefer giving indireclty because a charity organization does not get confused by "feelings" and is not easily manipulated. That is, when giving directly to the poor, Muslim donors, too, might have feelings. They might feel something akin to compassion. But precisely because they find such feelings problematic, some donors opt for more bureaucratized forms of giving. The turn to bureaucracy makes sense precisely because giving here is about calculation and a duty to God, not a compassionate attending to the poor, a form of care heavy with affect. At Mustafa Mahmoud, we encounter an ethics of care that is not tied to compassion - one that in fact at times can seem deeply uncompassionate. 


\section{The intake office}

Donors at Mustafa Mahmoud can fulfill their pious obligations without coming face-toface with the recipients. Yet in order to be able to give to God, they still need humans who eventually will receive their donations. By giving via the charity organization, donors outsource the decision of who should receive their alms. It is not obvious what the proper Islamic answer is to the question of who one should give to. On the one hand, a hadith says that one should give to a beggar "even if he arrives on a horse." That is, it is enough for someone to extend their hand; it is not up to the donor to judge deservingness. On the other hand, the Quran lists eight categories of legitimate alms recipients, constructing hierarchies of deservingness, and sometimes, in today's Egypt, feeding into bureaucratic machineries of assessment. The Quranic categories are featured on framed posters at Mustafa Mahmoud: (1) the poor, (2) the needy, (3) administrators of zakāt funds, (4) recent or potential converts, (5) freed slaves or those in bondage, (6) overburdened debtors, (7) those following the cause of God (today often interpreted to not only refer to warfare but also to building a society's infrastructure), and (8) travelers who need to return to their homes (Q 9:60; for details, see alQaradawi 2006). In actuality, at Mustafa Mahmoud today, only two categories matter, in conjunction with economic need: "sick" and "orphan" (meaning someone without a father). Even within these two categories, petitioners have to make a convincing case for the depth of their need and for their deservingness.

They try to do so in a different office, the intake office or "social research" (abhäth igtima 'iyya) office around the corner from the donation office. During the three hours every day that the office is open, from around $10 \mathrm{am}$ to $1 \mathrm{pm}$, dozens of people come in to plead their case. The office is crowded, hot, and filled with smoke. Three women in their forties work here and two men in their late twenties who are both chain-smokers. For the five employees, the daily routine is often boring but for the people coming in much is at stake. They tell their stories. They show the bodily marks of their ailments. They drag along their sick or disabled children, so they can present them to the employees. They hand over stacks of papers: medical documents, death certificates, and government papers. Based on this evidence, and sometimes additional home visits, the employees decide who is a case ( $h \bar{a} l a$ ) entitled to monthly support, who should receive a one-time token of support, and who should be turned away. The employees' work resembles that of people working in other welfare offices around the globe where the allocation of scarce resources always involves a "tragic choice" (Fassin 2012:45) places where "in return for the gift of fragments of their life, [petitioners] receive the countergift of a means of survival" (ibid. 81).

Telling the story of one's life and suffering often is not enough. The story also needs to be believed. Khaled, who is 28 years old and has been working at Mustafa Mahmoud for 8 years, explained to me that many of those coming in to plead for help do not actually deserve it. He claimed that $50 \%$ of the petitioners lie, and he explained that the employees frequently use a trick when talking to petitioners:

I'll ask: How many children do you have?

She says: four.

I look at her ID card and circle a [random] number on it, for instance ' 2 ' and say:

No, you have two! 
I watched Khaled and his colleagues use this trick many times - to throw petitioners off, to see how they react, and to make them admit they are not telling the truth. Often Khaled also explicitly accused petitioners of lying. This cold-hearted approach is exactly what donors appreciate about the organization. Many donors told me that they "trust" the organization and, as noted, they found that bureaucratized giving is better than immediate giving because it leaves out emotions. The employees, in turn, repeatedly reminded each other not to let their feelings take over. Yusra, a long-term employee, told me about a woman who had come in to ask for adult diapers for her handicapped teenage son. Yusra said the woman affected her deeply (sa 'bat 'alayya; literally: "she weighed heavily on me"). Then they found out that the son had died about a year earlier (meaning that the woman wanted to sell the diapers). For Yusra, this was a reminder that feelings need to be put aside when it comes to the question of who should receive aid.

The director of Human Resources put it this way:

It's wrong to go to a place like Sayyida Zaynab [a mosque and saint shrine] and to hand out alms or food there. How would you know that the people there really need help? It's random. You people from abroad, you understand this. You're practical. You can't do these things with your heart. You have to do them with your mind.

Echoing Khaled's claim, the director added that many of the petitioners lie but that the employees are skilled in discerning who is telling the truth and who is not: "They'll look at you and know you got married even though you say the opposite."

For the petitioners, visiting the intake office can be grueling. They cannot simply walk in and demand their rightful share, haqq al-faqir , the "right of the poor," the theoretical flipside of dutiful giving. They have to perform their suffering as best as they can. In a non-compassionate charitable economy, they try to evoke compassion, often unsuccessfully. The intake office reminds us of how messy things get when divine justice is translated into social exchanges. Looked at from the petitioners' end, Islamic charity is no less cruel than welfare in other places. What is different is that the pretense of compassion falls away.

\section{The disbursement office}

On the grounds of the mosque-complex, in front of the donation office, is another small office, known as the "disbursement office" (maktab al-sarf). Here registered recipients - those who have managed to become "cases" - collect their monthly share. They arrive in the early morning and drop off the identification card that the association has issued them. Besides their name and "condition," the card indicates the monthly amount to which they are entitled. Then they wait, spilling out into the square in front of the mosque-complex, sometimes literally rubbing shoulders with those who have arrived to donate and are squeezing their way through the crowd. After two or more hours of waiting, the recipients are called to the window of the disbursement office. 
Behind the window sits Ahmed. He has a suitcase with him, filled with bills. He moves the stacks of bills into a drawer in front of him: piles of 5, 20, and 50 EGP bills. Reading a list of names into a megaphone, he calls the recipients to the window, one by one. They come up to the window and receive their share-for most people, 50 or 65 EGP (roughly 10 USD). Then they sign a form, or, if they cannot write their names, they use a small personalized metal stamp to substitute for their signature.

Few say "thank you" or call upon God to bless Ahmed. Most say nothing. They take their share and walk away. I was often struck by the pervasive silence - by the absence of expressions of gratitude. One could read this silence in different ways. For one, it might simply be an effect of tiredness. The petitioners, many of whom are elderly, handicapped, or ill, had to get up early and had to take multiple means of public transportation to come to Mustafa Mahmoud, only to later make their rounds to other charity organizations. It is only by cobbling together aid from multiple sources that poor and low-income Egyptians can get by. This is hard work, or what James Ferguson (2015:94ff.) calls "distributive labor," which for him includes everything from begging to panhandling and pickpocketing. The petitioners' silence might also be an effect of the bureaucratization of charity (after all it is not Ahmed who is sharing his wealth with them but the absent donors). Or it could be a sign of the recipients' discontent, the fact that they had to wait in the heat for hours to receive this small token of support. But there is yet another way in which we can read the silence: as intimately tied to an economy of care that is not about compassion and suffering but rather about rightful shares.

The absence of gratitude is in line with an Islamic ethics of giving. In his work on almsgiving, the medieval philosopher Hamid al-Ghazali notes that one should not expect any gratitude from the recipients since all giving is directed at God and all gifts come from God (al-Ghazali 1966). In the 1960s, Sayyid Qutb, the key ideologue of the Muslim Brotherhood, wrote about almsgiving and its relation to social justice. He argued that Islam "labors to elevate the nature of both those who give and those who receive" by making giving a duty (Qutb 2000:108). The idea of duty, in his view, gets us around the illusion of generosity and a dynamic of indebtedness. He cites the example of 'Ali, the Prophet Muhammad's younger cousin, and 'Ali's wife Fatima, the daughter of the Prophet: They gave food to the poor, orphans, and prisoners, saying, "It is only for the sake of Allah that we give you food; we want from you neither reward nor gratitude."

The majority of alms recipients at Mustafa Mahmoud likely have not read al-Ghazali or Sayyid Qutb. Many of them are illiterate or, trying to make it from day to day, are too busy to devote themselves to studying the Islamic tradition. But they are nevertheless familiar with the logic of dutiful giving-from the Quran, mosque lessons, sermons, and informal conversations. Echoing this logic, alms recipients told me that, in theory, in Islam they are entitled to a part of the wealth of the well-off. That is, they should not have to beg for help. In a charitable economy that is not contingent on compassion, one should not have to perform one's suffering. But as those at the receiving end know all too well, rightful shares do not always reach their rightful owners. Petitioners have to convince donors and employees of their need and deservingness. At the moment when they receive their share, however, they are able to drive home the point that what they are receiving is their right and not a token of generosity. Alms are not something for which they should have to thank Ahmed or the donor. The money they are receiving rightfully belongs to them. 


\section{Conclusion}

Images of suffering - of the homeless, the malnourished, street children-seek to compel us to give. I see such images of suffering almost every day on posters during my subway commute through Toronto, on websites, and in magazines. Some charity organizations in Cairo use similar images of suffering in their TV ads and promotional materials. Sometimes such images move me and I end up donating. Most times they do not. Compassion is unstable and unreliable. But compassion is only one way of organizing a charitable economy. At the Mustafa Mahmood organization, we encounter another way.

By looking at three offices at this organization, I have sketched an ethics of giving that is organized around the idea of duty. In the donation office, donors drop off money because they believe that God has ordered them to do so and because they hope to be rewarded by God - in this life or the afterlife. Their giving is not driven by empathy or concern for those in need but rather is about protecting their remaining wealth and securing for themselves a place in paradise by fulfilling a central religious obligation. By taking care of others, they take care of themselves. In the intake office, we saw the other side of the coin: petitioners seeking to convince jaded employees of their need and deservingness. Their efforts at turning themselves into "cases" remind us that, despite the non-humanitarian framing, suffering matters, at least at times, within an Islamic economy of giving. The disbursement office brings us back full circle to the logic of entitlement. Here recipients receive their share without feeling compelled to offer a word of thanks in return. They take what is rightfully theirs.

Drawing together what people say and do in these different offices helps us see a form of care that is not committed to, or driven by, compassion. While maybe upsetting to liberal sensibilities, this non-compassionate ethics gets us around some of the more troubling aspects of compassion. To recall, critics of compassion have highlighted the ways in which it reinscribes privilege, its self-congratulatory nature, its selectiveness, the danger of compassion fatigue, and the ways in which humanitarian reason undermines a framework of rights. An Islamic ethics of giving, as interpreted by thinkers such as al-Ghazali and Sayyid Qutb but also by the many people whose paths converge at the Mustafa Mahmoud Association, disrupts the hierarchy between giver and recipient. The sufferer is not over there, but donor and recipient are both down here and equally indebted to God. The problem of selectiveness - the fact that the suffering of some moves us but not the suffering of others - and the danger of compassion fatigue play less of a role because affect takes the backseat. It does not matter whether you feel for those in need if feeling is not what drives the giving. Finally, an Islamic ethics of care is not dichotomously opposed to a logic of rights. Not necessarily legal rights but Quranically prescribed rights of the poor, tied to the idea of divine justice, are central to the economy of care I have described.

My goal in describing the giving and taking at Mustafa Mahmoud is not to romanticize an Islamic ethics of care. As we saw in the intake office, the poor cannot simply walk in and demand their rightful share. They have to work hard to become "cases," and much of this struggle involves attempts to evoke compassion-attempts that are frequently unsuccessful. At times, the form of care I have described can also slip from non-compassionate to absurd. Against her usual faith in bureaucratized giving, Yusra once told me about a young woman who was about to get married and 
had come to the Mustafa Mahmoud mosque to ask for help as she could not even afford an outfit for the occasion. An employee was randomly handing out items that a donor had dropped off the previous day. He gave the young woman a funeral shroud. She was so shocked that she ended up postponing her wedding. This is bureaucracy-or emotionless giving - at its worst.

What I hope to have shown, however, is that we should be wary of conflating "caring for" and "caring about." The ethos of giving I have described is driven by duty - the obligation to care for others - and not by compassion - an empathetic caring about others. "Caring for" does not necessarily translate into "caring about," nor are the two necessarily related. Donors at Mustafa Mahmoud frequently articulate caring for those in need in calculative terms as a way of "trading with God." Caring about those in need, by contrast, is avoided, in part precisely by channeling one's alms through a bureaucratic organization rather than handing them out directly. While such a seemingly careless form of care at first might seem cold and heartless, it offers a provocative alternative to the liberal illusion of "compassion." It points to an ethics of giving that is about piety-not pity.

\section{References}

al-Ghazali, A. H. (1966). The mysteries of almsgiving: A translation from the Arabic, with notes, of the Kitāb Asrār Al-Zakāh of Al-Ghazzāli's Ihyā 'Ulūm Al-Dīn. Beirut: American University of Beirut.

Al-Qaradawi, Y. (2006). Fiqh al-zakāt: dirāsa muqārina li-ahkāmiha wa falsafatiha fì daw' al-Qur'ān wa alsunna. Cairo: Maktabat al-Wahba.

Asad, T. (1986). The idea of an anthropology of Islam. Washington D.C: Center for Contemporary Arab Studies.

Asad, T. (1993). Genealogies of religion: Discipline and reasons of power in Christianity and Islam. Baltimore: Johns Hopkins University Press.

Atia, M. (2013). Building a house in heaven: Pious neoliberalism and Islamic charity in Egypt. Minneapolis: University of Minnesota Press.

Berlant, L. G. (2004). Introduction: Compassion (and Withholding). In L. Berlant (Ed.), In Compassion: The Culture and Politics of an Emotion (pp. 1-13). New York: Routledge.

Butler, J. (2006). Precarious life: The powers of mourning and violence. New York: Verso.

Clark, J. A. (2004). Islam, charity, and activism: Middle-class networks and social welfare in Egypt, Jordan, and Yemen. Bloomington: Indiana University Press.

Deeb, L. (2006). An enchanted modern: Gender and public piety in Shi'i Lebanon. Princeton: Princeton University Press.

Douglas, M. (1990). Foreword. In The Gift: The form and reason for exchange in archaic societies by Marcel Mauss (pp. ix-xxiii). London: Routledge.

Elisha, O. (2011). Moral ambition: Mobilization and social outreach in evangelical megachurches. Berkeley: University of California Press.

Fassin, D. (2012). Humanitarian reason: A moral history of the present. Berkeley: University of California Press.

Ferguson, J. (2015). Give a man a fish: Reflections on the new politics of distribution. Durham: Duke University Press.

Foucault, M. (1988). The history of sexuality, volume 3: The care of the self. New York: Vintage.

Hafez, S. (2011). An Islam of her own: Reconsidering religion and secularism in women's Islamic movements. New York: New York University Press.

Hirschkind, C. (2006). The ethical soundscape: Cassette sermons and Islamic counterpublics. New York: Columbia University Press.

Jouili, J. (2015). Pious practice and secular constraints: Women in the Islamic revival in Europe. Stanford: Stanford University Press. 
Mahmood, S. (2005). Politics of piety: The Islamic revival and the feminist subject. Princeton: Princeton University Press.

Mauss, M. (1967). The gift: Forms and functions of exchange in archaic societies. New York: Norton.

Mittermaier, A. (2012). Dreams from elsewhere: Muslim subjectivities beyond the trope of self-cultivation. The Journal of the Royal Anthropological Institute, 18(2), 247-265.

Mittermaier, A. (2013). Trading with God: Islam, Calculation, Excess. In J. Boddy \& M. Lambek (Eds.), A Companion to the Anthropology of Religion (pp. 274-293). Hoboken: John Wiley and Sons.

Mittermaier, A. (2014). Beyond compassion: Islamic voluntarism in Egypt. American Ethnologist, 41(3), 518-531.

Mittermaier, A. (2019). Giving to god: Islamic charity in revolutionary times. Oakland: University of California Press.

Naguib, N. (2015). Nurturing masculinities: Men, food, and family in contemporary Egypt. Austin: University of Texas Press.

Parry, J. (1986). The Gift, the Indian Gift and the 'Indian Gift.'. Man, 21(3), 453-473.

Qutb, S. (2000). Social justice in Islam. Oneonta: Islamic Publications International.

Salvatore, A. (2000). Social differentiation, moral authority and public Islam in Egypt: The path of Mustafa Mahmud. Anthropology Today, 16(2), 12-15.

Salvatore, A. (2001). Mustafa Mahmud: A paradigm of public Islamic entrepreneurship? In A. Salvatore (Ed.), Muslim Traditions and Modern Techniques of Power (pp. 211-224). Muenster: Lit Verlag.

Schielke, Samuli. 2010. "Second thoughts about the Anthropology of Islam, or how to make sense of grand schemes in everyday life." ZMO Working Paper Series 2.

Schielke, S. (2015). Egypt in the future tense: Hope, frustration, and ambivalence before and after 2011. Bloomington: Indiana University Press.

Sparre, Sara Lei. 2013. "A generation in the making: The formation of young Muslim volunteers in Cairo." $\mathrm{PhD}$ diss., Department of Anthropology, University of Copenhagen.

Sparre, S. L. (2018). Experimenting with alternative futures in Cairo: Young Muslim volunteers between God and the nation. Identities: Global Studies in Culture and Power, 25(2), 158-175.

Sullivan, D. J. (1994). Private voluntary organizations in Egypt: Islamic development, private initiative, and state control. Gainesville: University Press of Florida.

Ticktin, M. (2011). Casualties of care: Immigration and the politics of humanitarianism in France. Berkeley: University of California Press.

Trundle, C. (2014). Americans in Tuscany: Charity, compassion, and belonging. New York: Berghahn Books. Wilde, O. (1895). The soul of man under socialism. Portland: T.B. Mosher.

Publisher's note Springer Nature remains neutral with regard to jurisdictional claims in published maps and institutional affiliations. 